\title{
Nutritional Status and School Performance of Primary School Children in Ogun State, Nigeria
}

\author{
Ajuzie Nnenna Choice ${ }^{1}$, Sanusi Rasaki A², Makinde Yetunde 0 \\ ${ }^{1,3}$ Department of Nutrition and Dietetics, Ben Carson Snr School of Medicine, Babcock University, Ilishan Remo, Ogun \\ State, Nigeria.
}

${ }^{2}$ Department of Human Nutrition, University Of Ibadan, Ibadan, Oyo State, Nigeria

Received: July 17, 2018; Accepted: October 5, 2018; Published: November 9, 2018

*Corresponding author: Ajuzie Nnenna Choice, Department of Nutrition and Dietetics, Ben Carson Snr School of Medicine, Babcock University, Ilishan Remo, Ogun State, Nigeria; E-mail: ajuzie.choice@gmail.com

\begin{abstract}
The nutritional status of school-aged children impacts their health, cognition, and their educational achievement while poor health and malnutrition impair both the growth and cognitive development of primary school children. This study was carried out to assess the nutritional status and school performance of primary school children in Ogun state, Nigeria. A descriptive cross-sectional survey was conducted among 1200 pupils age 6-12 years old selected from 12 public Primary schools using multi-stage sampling techniques. Interviewer administered questionnaires were used to collect information on the socio-demographic variables of the subjects and also social economic variables of subject parents or guardians. Information on school performance was collected from the Ogun State Unified Examination record record from State Universal Basic Education Board (SUBEB). A 24 hour dietary recall method was used to collect information on the specific food intakes and usual portion sizes. Anthropometric measurements were measured using an electronic food weighing scale and height using a stadiometer. Data collected were subjected to descriptive, t-test and Chisquare statistics. Data on food intake were converted to nutrient intake using Total Diet Assessment software. Body Mass Index for age (BMI-for-Age) was calculated from anthropometric data generated using WHO Anthro software. Results shows that the mean and standard deviation age of the respondents were $11.04 \pm 1.082$ years while the minimum and maximum age was 8 years and 12 years old respectively. The mean weight range of the respondents was, $19.00 \mathrm{~kg}$ to $70.00 \mathrm{~kg}$ respectively. The mean height range was, $1.18 \mathrm{~m}$ to $1.63 \mathrm{~m}$. The mean mathematics, English Language, social studied scores was $58.64 \pm 13.740,61.14 \pm 14.086,64.88 \pm 14.386$ while minimum and maximum score were $20 \%$ and $99 \%, 19 \%$ and $99 \%$, $18 \%$ and $97 \%$ respectively. Less than $(47.1 \%)$ of the respondents have normal nutritional status while $45.80 \%$ were underweight, females were more underweight than male while male were overweight and obese than the female. School performance of the Respondents, $70.3 \%$ of the respondents had average score in mathematics, $22.3 \%$ performed excellently and $7.4 \%$ had poor performance. Over half of the respondents, $69.3 \%$ had average score in English language while $26.2 \%$ were excellent and $4.6 \%$ were poor. $57.8 \%$ had average performance, $38.2 \%$ had excellent and $4.0 \%$ had poor performances in social studies. Majority of the respondents had inadequate energy intake (83.8\%), $2.0 \%$ had excess energy intake while $14.3 \%$ are adequate energy intake, more than half of respondents (54.3\%) Carbohydrate intakes were inadequate while $39.8 \%$ had adequate carbohydrate intake and $5.9 \%$ had excess intake of carbohydrate. For Protein, $80.0 \%$ had inadequate protein intake, $17.3 \%$ had adequate protein intake while 2.8 had excess intake. $97.5 \%$ of the respondent had inadequate Fat intake while $1.8 \%$ had adequate intake and 0.8 had excess intake. $72.7 \%$ of the respondents had inadequate intake of Vitamin A, $17.0 \%$ had adequate intake, $10.3 \%$ had excess intake, for Vitamin C, $99.0 \%$ had inadequate intake, $0.8 \%$, had adequate intake, $0.3 \%$ had excess, $46.0 \%$ had inadequate intake of Folate, $21.5 \%$, had adequate intake, $32.5 \%$ had excess intake, for Calcium, $98.8 \%$ of the respondents had inadequate intake, $0.8 \%$, had adequate intake, $0.4 \%$ had excess intake, $89.0 \%$ of the respondents had inadequate of Zinc, 10.5 had adequate intake and $0.5 \%$ had excess intake, for Iron $51.0 \%$ of the respondents had inadequate intake, $34.3 \%$ had adequate intake and $14.8 \%$ had excess intake. Significant relationship existed between the Height-for-Age, BMI-for-Age and school performance of the respondents, as height of the pupils increases there is an increase in their school performance and their body mass index have a positive effect on their school performance which were significant $(p \leq 0.05)$ except mathematics score.
\end{abstract}

Key words: Nutritional status; School Performance; Anthropometry; School Age Children;

\section{Introduction}

The nutritional status of school-aged children impacts their health, cognition, and their educational achievement [3]. The school age is a dynamic period of growth and development. Poor health and malnutrition impair both the growth and cognitive development of primary school children [18]. Diets offered to young children are of low quality, lack variety, low energy and nutrient density, they are usually of and multiple nutrient deficiencies are common in this age group [14]. Understanding the nutritional status of children has far-reaching implications for promoting the health of future generations [2].
The prevalence of malnutrition is still high in Nigeria (52.7\%) [10]. Many children are malnourished which prevent them from reaching their optimum potential, because nutrition is a foundation on which human progress in built $[1,19]$. It is however sad that malnutrition has continued to be a public health problem in developing countries where poor socio-economic conditions has continued to work in synergy with malnutrition [20].

The nutritional status of school-aged children impacts their health, cognition, and their educational achievement [3]. The school age is a dynamic period of growth and development. Poor health and malnutrition impair both the growth and cognitive 
development of primary school children [18].Diets offered to young children are of low quality, lack variety, low energy and nutrient density, They are usually of and multiple nutrient deficiencies are common in this age group [14].

Improving nutrient intake of children is important for health and well-being of individual [21]. Many children are malnourished which prevent them from reaching their optimum potential, because nutrition is a foundation on which human progress in built $[1,19]$. It is however sad that malnutrition has continued to be a public health problem in developing countries [20].

The observation that many children in developing countries did not complete primary school and those who completed, did not do as well as children in developed countries, has kindled researchers' interest in the relationship between nutritional status, health and educational achievement of school aged children in developing countries [22].

This poor performance led the noble Laureate James Watson to express gloom about the future of Africa, in the light of the finding that sub-Saharan Africans have lower average test scores than the people in other parts [22], though this seemingly poorer performance of Africans on test scores has been attributed to culturally unfair test instruments [18].

A growing concern about the Nigerian educational system is that it is failing to meet the national need for a competitive work force. Evidence exists that for any nation to develop a competitive work force, school children need to be in optimal health and nutritional status [23].

Previous studies have shown that food eaten by school children during break time is poor in both quality and quantity. Also the average amount brought to school by pupils in primary school is five Naira (N 5) so small that food purchase with this amount has no significant effect on nutritional status [21]. In developing countries like Nigeria, using Ogun State as a case study, where child malnutrition is common, understanding the impact of nutritional status on schooling is of even greater importance and urgency. Therefore, a study of this nature especially among school age children in Ogun State is imperative and a dearth of valid research of nutritional status and school performance by pupils in southwest Nigeria is scanty.

\section{Materials and Methods}

\section{Sample and Sampling Techniques}

The study was descriptive and cross-sectional covering public primary schools in Ogun State. Primary school children of 6-12 years old range (not less than 6 years and not more than 12years) in the selected local government area of the 3 senatorial district in Ogun state.

\section{Sample size determination}

The minimum sample s ize was calculated using the statistical formula for calculating

minimum sample size, ( Scott Smith 2013) thus;

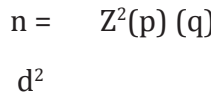

Where $\mathrm{Z}$ is the $\mathrm{Z}$ score value $95 \%$ confidence interval $(\mathrm{CI})=1.96$ $\mathrm{n}=$ Minimum Sample Size

$\mathrm{z}=1.96$

$\mathrm{d}$ is the precision $(0.05)$

$\mathrm{p}=52.7 \%$ (percentage of malnutrition in Nigeria) [10]

$\mathrm{q}=1-\mathrm{p}$

$\mathrm{n}=1.96^{2}(0.52)(0.48)$

$(0.05)^{2}$

$\mathrm{n}=384.16$

$10 \%$ of the minimum sample size was calculated using the formula above will be added to take care of attrition ,

Thus:

$$
10 \% \text { of } 384.16=38.416
$$

$384.16+38.416=422.5$

The sample size was approximately 423 from each of the Senatorial district in Ogun state and two Local Government Areas was selected from each of the Senatorial district it will be rounded up to 100 subjects from each of the Local Government Area making a total of 1200 sample size. of the 6 .

\section{Data collection}

An interviewed administered questionnaire written in English was administered to the selected respondents. The questionnaire has information on (personal data, socio-demographic and economic, school performance and 24-hour dietary recall). Information on school performance was collected from the Ogun unified examination record from State Universal Basic Education Board (SUBEB).

Data were collected in the following ways:

\section{Anthropometry Measurements}

\section{a) Weight Measurement}

Body weights were measured using an electronic scale (Health-0-Meter model HDM 691 D-01-95). The scale were place on a flat surface and the subjects were made to stand uprightly, barefooted, minimal clothing. The reading was done in duplicate to the nearest $0.1 \mathrm{~kg}$ and the average weight was calculated.

\section{b) Height Measurement}

Heights were measured using a stadiometer. The subjects were made to stand erect on the base place without shoes, socks, head tie in order to give accurate distance between the sole of the feet and head crown. The subjects are looking straight; the head piece was sliced down to the head crown. The height was taken to the nearest $0.1 \mathrm{~m}$ and repeated to obtain the average value. 


\section{c) Body Mass Index (BMI)}

This was determined by dividing the weight of each respondent in kilogram by the square of his/her height is meters [25].

$$
\text { BMI }=\frac{\text { Weight }(\mathrm{Kg})_{-}}{\text {(Height) } 2(\mathrm{~m} 2)}
$$

\section{Hours Dietary Recall}

A 24 hour dietary recall interview questionnaire was used to collect information on the specific food intakes and usual portion sizes.

\section{School Performance}

Pupils past result (School performance) was collected from the Ogun unified examination record from State Universal Basic Education Board (SUBEB).

\section{Data Analysis}

The data were scrutinized, cleaned and then entered into the computer for analyzed using statistical package for social science (SPSS) version 21. Data on anthropometric measurements were analyzed on the WHO Anthro-plus software and were compared with the WHO child growth standards 2006. The information on usual portion sizes reported on the 24 hour dietary recall questionnaire were converted into weight of food in grams and analyzed for adequacy in nutrient intake using the Adapted Total Dietary Assessment (TDA 1.0.4).The data generated were analyzed using descriptive statistics such as mean, standard deviation, percentage; frequency and correlation were carried out at $5 \%$ significance to elucidate the relationship between the nutritional status and school performance.

\section{Results}

\section{Respondents Personal Data}

Table 1, shows the pupils personal data such as ages of the pupils ranged from7 to 12 years, 7-9 years of age were $9.8 \%$ while $90.2 \%$ were 10 to 12 years of age. The mean age however was between 10-12years. Over half (54.1) of the respondents are female. About 58.8\% were Christians, 40.1 were Muslims while 1.1 were traditionalists. Majority $(90.8 \%)$ of the respondents
Table 1: Respondents Personal Data

\begin{tabular}{|c|c|c|}
\hline Age range (years) & Frequency \%) & Percentage (\%) \\
\hline $7-9$ & 118 & 9.8 \\
\hline $10-12$ & 1082 & 90.2 \\
\hline Total & 1200 & 100 \\
\hline Sex & & \\
\hline Male & 551 & 45.9 \\
\hline Female & 649 & 54.1 \\
\hline Total & 1200 & 100 \\
\hline
\end{tabular}

Religious Affiliation

\begin{tabular}{|c|c|c|}
\hline Christianity & 706 & 58.8 \\
\hline Islamic & 481 & 40.1 \\
\hline Traditional & 13 & 1.1 \\
\hline Total & 1200 & 100 \\
\hline Tribe & & \\
\hline Yoruba & 1090 & 90.8 \\
\hline Hausa & 39 & 2.9 \\
\hline Igbo & 55 & 5.5 \\
\hline Minority & 10 & 0.8 \\
\hline Total & 1200 & 100 \\
\hline
\end{tabular}

\section{Family Status}

\begin{tabular}{|c|c|c|}
\hline with both parents & 818 & 68.2 \\
\hline with father only & 78 & 6.5 \\
\hline with mother only & 187 & 15.6 \\
\hline with mother and step father & 47 & 3.9 \\
\hline with relations & 70 & 5.8 \\
\hline Total & 1200 & 100 \\
\hline
\end{tabular}

were Yoruba, 5.5\% were Igbo, 2.9\% Hausa and 0.8\% were from other ethnic groups.

Majority (68.2\%) of the respondents live with both parents, $15.6 \%$ with their mother, $6.5 \%$ with their father, $3.9 \%$ with their mother and step father and 5.8 with their relatives. (Table1\&2).

\begin{tabular}{|c|c|c|c|c|}
\hline Status & Frequency(no) Male & Percentage (\%) & Frequency(no) female & Percentage (\%) \\
\hline Under-weight & 165 & 13.75 & 383 & 32.05 \\
\hline Normal & 297 & 24.75 & 268 & 22.35 \\
\hline Over-weight & 60 & 5 & 51 & 4.3 \\
\hline Obese & 29 & 2.4 & 3 & 0.3 \\
\hline
\end{tabular}

Table 2: Nutritional Status of Respondents 
$47.1 \%$ of the respondents have normal nutritional status while $45.80 \%$ were underweight, females were more underweight than male while male were overweight and obese than the female (Table 3).

Majority of the respondents had average score in mathematics, $22.3 \%$ performed excellently and $7.4 \%$ performance was poor. Over half of the respondents, had average score in English language while $4.6 \%$ were poor and $26.2 \%$ were excellent. More than half of them had average performance, $38.2 \%$ excellent and $4.0 \%$ poor performances in social studies (Table 4 ).

Weight, Score in Mathematics, Score in English Language and Score in Social Studies variables were not significantly different in both sexes except, for height were significantly different in both sexes ( $\mathrm{p} \leq 0.05)$. The mean values for Weight is higher in boys than girls but it has no significant effect. Score in Mathematics, English Language and Social Studies, were higher in girls compared to the boys but have no significant effect (Table 5).

Significant relationship existed between the Height-for-Age, BMI-for-Age and school performance of the respondents, as height of the pupils increases there is an increase in their school performance and their body mass index have a positive effect on their school performance which were significant $(p \leq 0.05)$ except mathematics score (Table 6).
Table 3: School performance of the Respondents

\begin{tabular}{|c|c|c|}
\hline Subject & Frequency(no) & Percentage (\%) \\
\hline Mathematics & 89 & 7.4 \\
\hline Poor & 844 & 70.3 \\
\hline Average & 267 & 22.3 \\
\hline Excellent & & \\
\hline
\end{tabular}

English Language

\begin{tabular}{|c|c|c|}
\hline Poor & 55 & 4.6 \\
\hline Average & 831 & 69.3 \\
\hline Excellent & 314 & 26.2 \\
\hline Total & 1200 & 100.0 \\
\hline Social Studies & & \\
\hline Poor & 48 & 4 \\
\hline Average & 694 & 57.8 \\
\hline Excellent & 458 & 38.2 \\
\hline Total & 1200 & 100.0 \\
\hline
\end{tabular}

Table 4: Mean weight and height and school performance

\begin{tabular}{|c|c|c|c|}
\hline Variable & $\begin{array}{c}\text { Male (n=551) } \\
\text { (Mean } \pm \text { SD) }\end{array}$ & $\begin{array}{c}\text { Female (n=649) } \\
\text { (Mean } \pm \text { SD) }\end{array}$ & t-value \\
\hline Height (m) & $135.85+7.867$ & $136.86+8.323$ & -2.155 \\
\hline Weight (kg) & $40.52 \pm 8.574$ & $40.46 \pm 9.518$ & 0.108 \\
\hline Score in Math & $58.50 \pm 13.642$ & $58.76 \pm 13.831$ & -0.319 \\
\hline Score in English & $60.44 \pm 14.092$ & $61.74 \pm 14.063$ & -1.605 \\
\hline Score in Social Studies & $64.66 \pm 14.431$ & $65.07 \pm 14.356$ & -0.482 \\
\hline *Statistically significant $(p<0.05)$ & & & 0.109 \\
\hline
\end{tabular}

Table 5: Relationship between Nutritional Status and School Performance

\begin{tabular}{|c|c|c|}
\hline Table 5: Relationship between Nutritional Status and School Performance & Height for Age & $0.001^{*}$ \\
\hline English Language score & $-0.025^{*}$ & $0.002^{*}$ \\
\hline Social studies score & $-0.017^{*}$ & $-0.071^{*}$ \\
\hline Mathematics score & $-0.003^{*}$ & \\
\hline *Statistically significant $(\mathrm{p} \leq 0.05)$ & & \\
\hline
\end{tabular}


Nutritional Status and School Performance of Primary School Children in Ogun State, Nigeria

Table6: Nutrient Intake of the respondents

\begin{tabular}{|c|c|c|c|c|}
\hline \multirow[t]{2}{*}{ Nutrient } & \multicolumn{2}{|c|}{ Male } & \multicolumn{2}{|c|}{ Female } \\
\hline & Frequency(no) & Percentage (\%) & Frequency(no) & Percentage (\%) \\
\hline \multicolumn{5}{|c|}{ Energy (Calorie) } \\
\hline Inadequate & 137 & 34.3 & 198 & 49.5 \\
\hline Adequate & 27 & 6.8 & 30 & 7.5 \\
\hline Excess & 2 & 0.5 & 6 & 1.5 \\
\hline \multicolumn{5}{|l|}{ Protein (g) } \\
\hline Inadequate & 123 & 30.8 & 197 & 49.3 \\
\hline Adequate & 38 & 9.5 & 31 & 7.8 \\
\hline Excess & 5 & 1.3 & 6 & 1.5 \\
\hline \multicolumn{5}{|c|}{ Carbohydrate (g) } \\
\hline Adequate & 70 & 17.5 & 89 & 22.3 \\
\hline Excess & 12 & 3.0 & 12 & 3.0 \\
\hline \multicolumn{5}{|l|}{ Fat (g) } \\
\hline Inadequate & 163 & 40.8 & 227 & 56.8 \\
\hline Adequate & 1 & 0.3 & 6 & 1.5 \\
\hline Excess & 2 & 0.5 & 1 & 0.3 \\
\hline \multicolumn{5}{|l|}{ Calcium (mg) } \\
\hline Inadequate & 163 & 40.8 & 232 & 58 \\
\hline Adequate & 2 & 0.5 & 1 & 0.3 \\
\hline Excess & 1 & 0.2 & 1 & 0.3 \\
\hline Inadequate & 147 & 36.8 & 209 & 52.3 \\
\hline Adequate & 19 & 4.8 & 22 & 5.5 \\
\hline Excess & 0 & 0 & 3 & 0.8 \\
\hline \multicolumn{5}{|l|}{ Iron (mg) } \\
\hline Inadequate & 82 & 20.5 & 122 & 30.5 \\
\hline Adequate & 62 & 15.5 & 75 & 18.8 \\
\hline Excess & 22 & 5.5 & 37 & 9.3 \\
\hline \multicolumn{5}{|c|}{ Vitamin A (mg) } \\
\hline Inadequate & 119 & 29.7 & 172 & 43.0 \\
\hline Adequate & 30 & 7.5 & 38 & 9.5 \\
\hline Excess & 17 & 4.3 & 24 & 6.0 \\
\hline \multicolumn{5}{|c|}{ Vitamin C (mg) } \\
\hline Inadequate & 165 & 41.3 & 231 & 57.8 \\
\hline Adequate & 1 & 0.3 & 2 & 0.5 \\
\hline Excess & 0 & 0.0 & 1 & 0.2 \\
\hline \multicolumn{5}{|l|}{ Folate (mg) } \\
\hline Inadequate & 67 & 16.8 & 117 & 29.3 \\
\hline Adequate & 38 & 9.5 & 48 & 12.0 \\
\hline Excess & 61 & 15.3 & 69 & 17.3 \\
\hline
\end{tabular}


Majority of the respondents had inadequate energy intake (83.8\%), 2.0\% had excess energy and $14.3 \%$ are adequate, more than half of respondents $54.3 \%$ Carbohydrate intakes were inadequate while $39.8 \%$ had adequate or normal and $5.9 \%$ had excess carbohydrate intake. For Protein, $80.0 \%$ were inadequate, $17.3 \%$ adequate or normal while 2.8 were excess. $97.5 \%$ of the respondent had inadequate of Fat while $1.8 \%$ adequate and 0.8 excess. For Vitamin A ,Vitamin C Folate, Calcium, Zinc, Iron were $72.7,99.0 \%, 46.0 \%, 98.8 \%, 89.0 \%, 14.8 \%$ inadequate respectively while $17.0 \%, 0.8 \%, 21.5 \%, 0.8 \%, 10.3,51.0 \%$ are adequate and $10.3 \%, 0.3 \%, 32.5 \%, 0.5 \%, 0.8 \%, 34.3 \%$ are in excess.

\section{Discussion}

The study sought to assess the nutritional status and school performance of primary school children. The studies of the effect of malnutrition on cognitive ability indicate that chronic under nutrition is associated with lower achievement levels in school children [8]. Body mass and height are the most important measures of growth, development and reflect health condition and maturity of an individual [4]. The finding from this study is similar to one found in literature about the prevalence of severe stunted [17]. Finding from the study shows that male were heavier than female with no significant difference between male and female weight, height shows significant difference between the male and female but female were more stunted than male in contrast to the study found in literature [12] which reported boys as having significantly higher body mass and increased stature in a study conducted on rural South African school children aged 5 to 14 years.

However, the BMI values obtained from literature are lower than the BMI values in this study [13]. With the use of boundary BMI values, the percentage of overweight and obese of respondents were calculated in the group of respondents examined [5]. Obesity 2.7\% Overweight 9.3\%. BMI-for-age however, might not necessarily be appropriate in suggesting that so many of this study's children are largely exempt from overweight or obesity. The BMI values may actually be misleading due to the body proportions of these children. Little is known regarding specific BMI values in primary school children and their relationships with concurrent or future risks and that the BMI-for-age curves do not necessarily 'provide a desirable pattern that should be used as a healthy goal for school age children internationally' $[6,16]$.

Offering primary school children the right food choices and helping them develop positive and healthy eating habits will support optimal functioning of the brain.

The finding from the research shows that almost all the children are deficient in the entire nutrient intake and more than half of the respondents' academic performances were average which agrees the one found in literature, that the effect of malnutrition on cognitive ability indicated that chronic under nutrition is associated with lower achievement levels in school children. Significant relationship existed between the Height-forAge, BMI-for-Age and school performance of the respondents, as height of the pupils increases there is an increase in their school performance and their body mass index have a positive effect on their school performance which were significant ( $p \leq$ 0.05 ) except mathematics score which is in line with the finding that nutrition affects learning and behavior and suggested that diet can influence cognition and behavior in many ways, which include the condition of not enough nutrition or the condition of the lack of certain nutrients. These children also showed poor school performance as compared to those children who had an adequate intake of fruits and vegetables [9].

\section{Conclusion}

The relationship between nutritional status and school performance of the school children in the study location support those reported in the literature that the effect of malnutrition on cognitive ability indicate that chronic under nutrition is associated with lower achievement levels in school. The quantity and quality of food served in the school by the vendor should be able to meet the dietary needs of the primary school children.

Therefore, findings from this study can be used for nutrition education as parent's educational level has a significant relationship with the nutritional status of their children which will have effect on the children school performance.

\section{Recommendation}

There is need to encourage family to provide adequate diet for children that is up to the recommended daily allowance for both sex. And parents should increase the amount of money given to their children so that they can purchase food that can meet their dietary need. Need to increase nutritional awareness among parents through nutrition education.

\section{References}

1. 4th Report on the world nutrition situation. Nutrition throughout the life cycle. United Nations Administrative Committee on Nutrition (ACC/SCN) in collaboration with International Food Policy Research Institute (IFPRI). 2000;4-12.

2. Srivastava A, Mahmood SE, Srivastava PM, Shrotriya VP and Kumar B. Nutritional status of school-age children - A scenario of urban slums in India. Arch Public Health. 2012;70(1):8.

3. Best C, Neufingerl N, Van Geel L, Van den Briel T, Osendarp S. The nutritional status of school-aged children: why should we care? Food NutrBull. 2010; 31(3):400-417.

4. Bozic-Krstic VS, Pavlica TM and Rakic R S. Body height and weight of children in Novi Sad. Annals of Human Biology, 2004;31(3): 356-363.

5. Cole TJ, Freeman JV and Preece MA. Body mass index reference curves for the United Kingdom. 1990. Archives of Disease in Childhood. 1995;73(1):25-29.

6. De Onis M, Onyango AW, Borghi E, Siyam A, Nishida C, and Siekmann J. Development of a WHO growth reference for school-aged children and adolescents. Bulletin of the World Health Organization. 2007;85(9):660-667. 
7. Ernesto P. Malnutrition and Infection in the Classroom. UNESCO: Paris. 1990;45-48.

8. Grantham-McGregor SM, C.C. Ani. Undernutrition and mental development. In JD.2001;5:1-18.

9. Grantham-McGregor S.M, Ani C. A review of studies on the effect of iron deficiency on cognitive development in children. Journal of Nutrition.2001;131(2):649-668. doi: 10.1093/jn/131.2.649S

10. Goon TD, Toriola LA, Shaw SB, Amusa OL, Monyeki AM, Akinyemi o. et al. Anthropometrically determined nutritional status of urban primary school children in Makurdi, Nigeria. BMC Public Health. 2011;11:769.

11. Levinger B. Nutrition, Health and Education for All. Newton, M.A. (Ed). Education Development Centre.1996;20-24.

12. Mantsena M, Monyeki KD, Toriola AL. Sex differences in percentage body fat of Ellisras children. Journal of Human Movement Studies. 2002;43:443-454.

13. Monyeki MA, Koppes LLJ, Kemper HC G, Monyeki KD, Toriola AL, Pienaar, A. E. et al. Body composition and physical fitness of undernourished South African rural primary school children. European Journal of Clinical Nutrition. 2005;59(7): 877-883.

14. Ogbimi G.E, Ogunba BO. Nutritional quality of the lunches of children in day care in Osun State of Nigeria. African Journal of Food, Agriculture, Nutrition and Development. 2011;11(4): 1-11.

15. Oldewage-Theron WH, B Egal AA. Nutrition knowledge and nutritional status of primary school children in QwaQwa. S Afr J Clin Nutr. 2010;23(3):149-154.
16. Pawloski LR, Moore JB, Lumbi L.and Rodriguez P. A cross sectional examination of growth indicators from Nicaraguan adolescent girls: a comparison of anthropometric data from their Guatemalan counterparts. Annals of Human Biology, 2004;31(6):647-659.

17. Pollitt E. Malnutrition and Infection in the Classroom. UNESCO, Paris.1990;150-151.

18. Singh V, West KP Jr. Vitamin A deficiency and xerophthalmia among school-aged children in Southeastern Asia. Eur J ClinNutr. 2004;58(10):1342-1349.

19. Veneman AM. 30th SCN Annual session symposium on to end child hunger and under nutrition. UNICEF. Geneva.2011.

20. Olusanya BO, Wirz SL, Renner JK. Prevalence, pattern and risk factors for under nutrition in early infancy using the WHO Multicentre Growth Reference: a community-based study. Paediatric and Perinatal Epidemiology. 2010;24:572-583. doi: 10.1111/j.13653016.2010.01144.x

21. Edun BT, Adesanwo AS. Nutrient Adequacy Of Lunch Sold To Pupils By Vendors In Some Selected Primary Schools In Ondo State, Nigeria. IOSR Journal of Pharmacy and Biological Sciences (IOSR-JPBS). 2013;7(4):61-63.

22. Wicherts JM, et al. Raven's test performance of sub-Saharan Africans: Average performance, psychometric properties, and the Flynn Effect. Learning and Individual Differences. 2010;20(3)135-151. doi:10.1016/j.lindif.2009.12.001

23. Osisioma I. Rethinking the Nigerian educational reform process: Lessons from selected nations with unprecedented economic growth. International Journal of Educational Research. 2010;11(3):631. 